\title{
Large-scale, prospective, observational studies in patients with psoriasis and psoriatic arthritis: A systematic and critical review
}

\author{
Sue Langham ${ }^{1 *}$, Julia Langham² ${ }^{2}$ Hans-Peter Goertz ${ }^{3}$ and Mark Ratcliffe ${ }^{1}$
}

\begin{abstract}
Background: Observational studies, if conducted appropriately, play an important role in the decision-making process providing invaluable information on effectiveness, patient-reported outcomes and costs in a real-world environment. We conducted a systematic review of large-scale, prospective, cohort studies with the aim of (a) summarising design characteristics, the interventions or aspects of the disease studied and the outcomes measured and (b) investigating methodological quality.

Methods: We included prospective, cohort studies which included at least 100 adults with psoriasis or psoriatic arthritis. Studies were identified through searches in electronic databases (Pubmed, Medline, Cochrane library, Centre for Reviews and Dissemination). Information on study characteristics were extracted and tabulated and quality assessment, using a checklist of 18 questions, was conducted.
\end{abstract}

Results: Thirty five papers covering 16 cohorts met the inclusion criteria. There were ten treatment-related studies, only two of which provided a comparison between treatments, and six non-treatment studies which examined a number of characteristics of the disease including mortality, morbidity, cost of illness and health-related quality of life. All studies included a clinical outcome measure and 11 included patient-reported outcomes, however only two studies reported information on patient utilities and two on costs. The quality of the assessed studies varied widely. Studies did well on a number of quality assessment questions including having clear objectives, documenting selection criteria, providing a representative sample, defining interventions/characteristics under study, defining and using appropriate outcomes, describing results clearly and using appropriate statistical tests. The quality assessment criteria least adhered to involved questions regarding sample size calculations, describing potential selection bias, defining and adjusting for confounders and losses to follow-up, and defining and describing a comparison group.

Conclusion: The review highlights the need for well designed prospective observational studies on the effectiveness, patient-reported outcomes and economic impact of treatment regimes for patients with psoriasis and psoriatic arthritis in a real-world environment.

\section{Background}

Psoriasis is a chronic, non-contagious skin disease that commonly leads to appearance of red scaly patches on the skin. Psoriatic arthritis is a chronic, disabling inflammatory disease, associated with psoriasis. In psoriatic arthritis patients, the immune system attacks its own joints thus leading to joint destruction associated with cartilage deterioration, bone damage and joint fusion.

\footnotetext{
* Correspondence: suelangham@phmrconsulting.com

${ }^{1}$ PHMR consulting, London, UK

Full list of author information is available at the end of the article
}

Prevalence of the disease is around 2-3\% of the world population. It causes considerable morbidity, significantly affecting the quality of life of those suffering from the disease [1-5]. Psoriasis is linked with psychological distress [6], depression $[7,8]$, pain and physical disability [9]. In addition it carries significant economic implications, due to direct costs of management and costs associated with productivity losses [10-13]. Furthermore, there is some evidence to suggest that psoriasis and psoriatic arthritis may be associated with the development of heart disease, cancer and infections leading to premature death [14-17].

\section{Biomed Central}


There are a number of systemic treatments for psoriasis and psoriatic arthritis which have been examined in numerous randomised controlled trials (RCTs) $[18,19]$. However, while RCTs are considered the gold standard for evidence-based decision making, it has been argued that observational studies have an important role in the measurement of effectiveness, longer-term outcomes, rare adverse events, and other outcomes requiring a more naturalistic study environment, for example the measurement of resource use and health-related quality of life (HRQOL) [20,21]. RCTs are generally designed to test efficacy and safety. Although efficacy and effectiveness both address the issue of whether a particular intervention works or not, efficacy assesses whether an intervention works under optimal circumstances, whereas effectiveness assesses whether an intervention works in usual care. Effectiveness is meant to be a more pragmatic measure that addresses the utility of a drug as it is actually employed in practice, therefore to measure effectiveness it is necessary to mirror a real-world environment as much as possible. RCTs often use narrow inclusion criteria and exclude patients with specific comorbidities. In addition, sample sizes can be restricted and follow-up periods short. Such design characteristics mean that RCTs often have low external validity (how results can be generalised to the wider population) which limits their use in guiding treatment in routine clinical practice.

An observational study, by definition, is a study in which the investigators do not seek to intervene, only observe the course of events. Changes or differences in one characteristic (e.g. whether or not people received systemic treatment) are studied in relation to changes or differences in other characteristics (e.g. whether or not HRQOL improved), without action by the investigator. Such studies have high external validity but lower internal validity than RCTs. Results are more generalisable, but it is more difficult to attribute differences in outcomes between comparison groups to the particular intervention or characteristic under observation because of potential differences in baseline patient characteristics or because of losses to followup. It is important therefore for observational studies to be well designed and constructed and employ techniques to minimise the susceptibility of bias. Of the three types of observational study (cohort, cross-sectional and case-control), the cohort study stands at the top of the hierarchy of clinical observational evidence as it measures events in temporal sequence and can thereby more easily distinguish cause from effect. It is the most appropriate method to measure incidence of specific events, the natural history of the disease, changes in health states and use of healthcare resources.

Observational studies can play an important role in the decision-making process. The National Institute of
Clinical Excellence stresses that decision-makers need to assess and appraise all the available evidence regardless of whether it has been derived from a RCT or an observational study. In the United States comparative effectiveness research (i.e. the direct comparison of existing health care interventions to determine which work best for which patients and which pose the greatest benefits and harms) assesses effectiveness in patients typical of day to day clinical care and therefore the focus is on 'real life' studies rather than RCTs. Such comparative effectiveness research is being employed by the government to improve the quality of health care whilst reducing the rising costs. Both approaches have their strengths and weaknesses and it is important for decision-makers to understand these when using the evidence to inform them of the appropriate use of interventions in routine clinical practice [22]. Response to treatment in patients with psoriasis is unpredictable and often patients become resistant. This leads to individualised treatment regimes. The restrictive nature of RCTs would not necessarily highlight the outcomes that would be seen usual clinical practice where patients are often exposed to a number of different treatment regimes before response is achieved. Also as some of the treatments are associated with potentially serious sideeffects, longer-term observational studies can provide important additional information to a variety of stakeholders including clinicians, payers, providers and patients when weighing up the risks and benefits of treatment.

We carried out a comprehensive review of large-scale, prospective, cohort studies conducted on patients with psoriasis and psoriatic arthritis. Our primary aim was to (a) summarise the design characteristics, the interventions or aspects of the disease studied and the outcomes measured and (b) investigate the methodological quality of included studies.

\section{Methods}

We included prospective, cohort studies which included at least 100 adults with psoriasis or psoriatic arthritis. We included 'treatment' studies that focused on a particular intervention, drug or group of drugs with any comparison and 'non-treatment' studies that assessed the impact on psoriasis or psoriatic arthritis on morbidity, mortality, resource use or HRQOL. We excluded all studies with an experimental element to them (RCTs, open-label studies and open-label extensions). We also excluded retrospective studies, cross-sectional studies, studies where patient's age was less than 18 years old and unpublished studies. We employed a cut-off of 100 patients to define large scale because (a) a recent health technology assessment of the management of psoriasis employed this cut-off for observational studies [23] and 
(b) other studies have used this as a cut-off to define large scale studies [24].

A systematic electronic literature search was conducted to identify published reports using the following databases; PUBMED (1965 to 2009), MEDLINE (1989 to 2009), Cochrane Library (which includes Cochrane reviews, other reviews, clinical trials, methods studies, technology assessments and economic evaluations), the Centre for Reviews and Dissemination Database (which includes the Database of Abstracts of Reviews of Effects, NHS Economic Evaluation Database, Health Technology Assessment Database) and one internet search engine (google). Additionally the following databases were reviewed to search for ongoing and planned studies; TRIP Turning Research into Practice database, National research register, ClinicalTrials.gov, Current Controlled Trials, Early Warning System and Salford database of psoriasis trials. Search terms combined disease terms (psoriasis and psoriatic arthritis) with study types (cohort, epidemiologic, follow-up, longitudinal, prospective, registries, Phase IV, observational). Studies were restricted to those in humans and in the English language. For example the search string used in PUBMED and MEDLINE was ("Psoriasis/drug therapy"[Mesh] OR "Psoriasis/economics"[Mesh] OR "Psoriasis/epidemiology"[Mesh] OR "Psoriasis/prevention and control"[Mesh] OR "Psoriasis/ statistics and numerical data"[Mesh] OR "Psoriasis/therapy"[Mesh] OR "Arthritis, Psoriatic/drug therapy"[Mesh] OR "Arthritis, Psoriatic/epidemiology"[Mesh] OR "Arthritis, Psoriatic/prevention and control"[Mesh] OR "Arthritis, Psoriatic/therapy"[Mesh]) AND ("Cohort Studies"[Mesh] OR "Epidemiologic Studies"[Mesh] OR "Follow-Up Studies"[Mesh] OR "Longitudinal Studies"[Mesh] OR "Prospective Studies"[Mesh] OR "Registries"[Mesh] OR "Clinical Trials, Phase IV as Topic"[Mesh] OR "open label"[All Fields] OR "observational").

Titles and abstracts from the initial search were reviewed to identify relevant papers. A full paper review was then conducted on all those that met the general inclusion criteria. Reference lists of relevant studies were also hand searched to identify additional data. Contact with authors was not deemed necessary for the questions posed in this systematic review. Of those papers thought to be eligible, data on study characteristics were extracted and tabulated. Information collected included study design, objectives, patients, outcome measures, results, statistical methods and funding sources.

A quality assessment was conducted on all included studies. Although there are now guidelines on the reporting of observational studies (Strengthening the Reporting of Observational Epidemiological studies STROBE) [25] which guide the author how to present their data, there are no consensus guidelines on quality assessment of such studies. A multitude of tools exist that claim to assess the validity of published observational studies [26]. We devised our own quality assessment tool based on a number of papers including the Downs and Black score system [27], the STROBE statement [25] and a recent systematic review of measures for assessing quality and susceptibility to bias in observational studies [26]. Each study was assessed against a list of 18 questions outlined in table 1 . All results were summarised descriptively.

\section{Results}

A total of 1018 papers were identified from the combination of searches (Figure 1). Fifty-eight papers were obtained for full paper review, of which 35 papers were identified as eligible for inclusion into the review. Reasons for exclusion included study design was experimental [28-43], sample size too small [44], the patients included were originally from a clinical trial [3,45-51], the study involved retrospective identification of patients $[14,15,52-54]$ and the study was just a description of medications used with no attempt to assess outcomes [55].

The thirty-five papers relate to 16 observational studies, of which five were registry studies (Table 2). Nine were studies of psoriasis, six of psoriatic arthritis and one combined both conditions. Of the ten treatmentrelated observational studies only four evaluated biological agents; with the other six examining traditional therapies. Only two provided a comparison between two treatments. Of the six non-treatment related observational studies a number of characteristics of psoriasis and psoriatic arthritis were examined including mortality, morbidity, disease progression, cost of illness and aspects of HRQOL. Follow-up periods ranged from 3 months to 26 years.

Table 3 outlines the clinical, patient-reported and cost measurements described in each of the studies. The main clinical outcome measure used in the psoriasis studies was the Psoriasis area and severity index (PASI), with some studies using the self-administered version of this measurement (SPASI). In the psoriatic arthritis studies the most common clinical measurements were those relating to tender and swollen joint counts with three of the studies using the disease activity score-28 (DAS) based on 28 tender and swollen joint counts. Eleven studies incorporated patient-reported outcomes into their analysis. The most common patient-reported outcome was the health assessment questionnaire (HAS) used in six studies, followed by the SF-36 used in five studies. One study used a questionnaire on experiences with skin complaints (QES) and one used the dermatology life quality index (DLQI). Only two studies assessed health utilities either using the EQ-5D or the SF-6D and again only two studies reported information on costs. 
Table 1 Quality assessment tool

\begin{tabular}{|c|c|}
\hline Item & Question \\
\hline \multirow[t]{4}{*}{ Patients/selection bias } & 1) Is the hypothesis/aim/objective of the study clearly described? \\
\hline & 2) Are the characteristics of the patients included in the study clearly described? \\
\hline & 3) Is the patient sample representative of patients treated in routine clinical practice? \\
\hline & 4) Is there information on possibility of selection bias present in study? \\
\hline Interventions & $\begin{array}{l}\text { 5) Are the interventions of interest clearly described? Treatments should be clearly described. In non-treatment related } \\
\text { observational studies the characteristics under study should be clearly described. }\end{array}$ \\
\hline Comparison & 6) Was a comparison group identified and clearly defined? \\
\hline \multirow[t]{3}{*}{ Outcomes } & $\begin{array}{l}\text { 7) Are the main outcomes to be measured clearly described in the Introduction or Methods section? If the main } \\
\text { outcomes are first mentioned in the Results section, the question should be answered no. }\end{array}$ \\
\hline & $\begin{array}{l}\text { 8) Were the main outcome measures used accurate (valid and reliable)? For studies where the outcome measures are } \\
\text { clearly described, the question should be answered yes. For studies which refer to other work or that demonstrates the } \\
\text { outcome measures are accurate, the question should be answered as yes. }\end{array}$ \\
\hline & $\begin{array}{l}\text { 9) Have all important adverse events that may be a consequence of the intervention been reported? This should be } \\
\text { answered yes if the study demonstrates that there was a comprehensive attempt to measure adverse events. (A list of } \\
\text { possible adverse events is provided). }\end{array}$ \\
\hline \multirow[t]{3}{*}{$\begin{array}{l}\text { Reported findings/statistical } \\
\text { analysis }\end{array}$} & $\begin{array}{l}\text { 10) Are the main findings of the study clearly described? Simple outcome data (including denominators and } \\
\text { numerators) should be reported for all major findings so that the reader can check the major analyses and conclusions. } \\
\text { (This question does not cover statistical tests which are considered below) }\end{array}$ \\
\hline & $\begin{array}{l}\text { 11) Does the study provide estimates of the random variability in the data for the main outcomes? In non normally } \\
\text { distributed data the inter-quartile range of results should be reported. In normally distributed data the standard error, } \\
\text { standard deviation or confidence intervals should be reported. If the distribution of the data is not described, it must be } \\
\text { assumed that the estimates used were appropriate and the question should be answered yes. }\end{array}$ \\
\hline & $\begin{array}{l}\text { 12) Were the statistical tests used to assess the main outcomes appropriate? The statistical techniques used must be } \\
\text { appropriate to the data. For example nonparametric methods should be used for small sample sizes. Where little } \\
\text { statistical analysis has been undertaken but where there is no evidence of bias, the question should be answered yes. If } \\
\text { the distribution of the data (normal or not) is not described it must be assumed that the estimates used were } \\
\text { appropriate and the question should be answered yes. }\end{array}$ \\
\hline \multirow[t]{2}{*}{ Confounding } & $\begin{array}{l}\text { 13) Are the distributions of principal confounders in each group of subjects to be compared clearly described? A list } \\
\text { of principal confounders is provided. }\end{array}$ \\
\hline & 14) Was there adequate adjustment for confounding in the analyses from which the main findings were drawn? \\
\hline \multirow[t]{2}{*}{ Losses to follow-up } & 15) Were losses of patients to follow-up reported? \\
\hline & $\begin{array}{l}\text { 16) Were losses of patients to follow-up taken into account? If the numbers of patients lost to follow-up are not } \\
\text { reported, the question should be answered as unable to determine. If the proportion lost to follow-up was too small to } \\
\text { affect the main findings, the question should be answered yes. }\end{array}$ \\
\hline \multirow[t]{2}{*}{ Power } & 17) Was a sample size calculation reported? \\
\hline & $\begin{array}{l}\text { 18) Did the study have sufficient power to detect a clinically important effect where the probability value for a } \\
\text { difference being due to chance is less than } 5 \% \text { ? Sample sizes have been calculated to detect a difference of } x \% \text { and } y \% \text {. }\end{array}$ \\
\hline
\end{tabular}

Overall the quality of the included cohort studies, measured against a checklist of 18 questions, ranged from $41 \%$ to $89 \%$ (taking into account the questions that were not applicable for certain studies) (Table 4). Figure 2 outlines the proportion of the 16 studies that met each of the quality assessment criteria. The studies in general did well on a number of quality assessment questions including having clear objectives, documenting selection criteria, providing a representative sample, defining interventions/characteristics under study, defining and using appropriate outcomes, describing results clearly and using appropriate statistical tests (where described). However, the studies fell short on a number of other quality assessment criteria. Only one study reported a sample size calculation or reported whether the sample size was sufficient for the study objectives. Only a third described potential selection bias. Around
$50 \%$ described potential confounders and only a third adjusted for these potential confounders. Also, although over $60 \%$ reported losses to follow-up, less than a third made any adjustments for them in the analysis. Only around $60 \%$ of all studies identified and described a comparison group. Overall the proportion of studies meeting each quality assessment criteria ranged from $10 \%$ (sample size calculation and sufficient power) to $100 \%$ (patient characteristics described, validity of outcomes and results clearly described).

\section{Discussion}

Three important points can be concluded from this systematic review of large scale, prospective, observational studies conducted in patients with psoriasis or psoriatic arthritis. First, very few large-scale, prospective, observational studies have been conducted given the burden of 


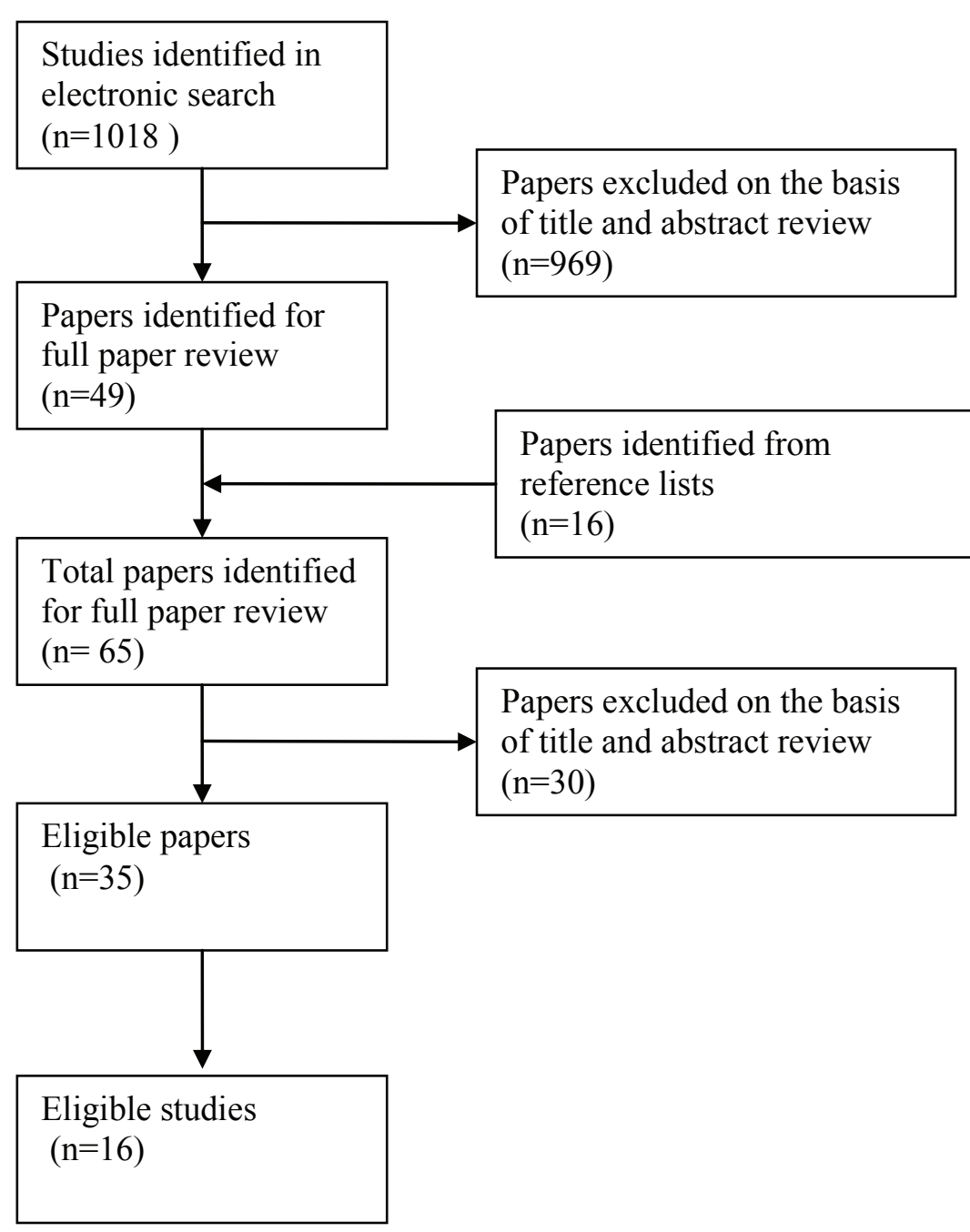

Figure 1 Flow diagram of included studies.

these diseases on society and the recent introduction of biologic agents onto the market, with only two assessing a drug versus drug comparison. Psoriasis is the most prevalent autoimmune disease in the United States. It affects 125 million people worldwide (2-3\% of the total population). Between 10 and $20 \%$ of people with psoriasis will develop psoriatic arthritis [56]. These conditions cause significant morbidity and have been associated with an increased risk of mortality compared to the general population [17]. They significantly affect a patient's HRQOL and ability to carry out normal activities [4] and the cost burden to society is substantial. In the United States psoriasis alone costs society $\$ 11.25$ billion annually, with work loss accounting for $40 \%$ of this cost burden [57]. The recent introduction of biological therapies represent an important addition to the approaches used in the treatment of psoriasis and psoriatic arthritis, however very few studies have assessed these agents in real-life situations compared to the more traditional treatments where many patient and provider factors, not present in clinical trial environments, can impact on effectiveness [58]. Also, in some countries these agents are registered for use in specific target groups of patients where evidence of efficacy and safety are not provided by currently published clinical trials [58]. Finally, clinical trial data only provide short-term evidence of efficacy and safety in a highly selected group of patients. For all these reasons large scale, long-term observational studies in real-life situations are needed to guide appropriate clinical and policy decision making.

Second, given the importance of collecting health economic data in a real world environment [20], very few observational studies collected data on economic outcomes or patient utilities. In the general hierarchy of clinical evidence in healthcare decision making, RCT's remain the gold standard for evaluation. However, there 
Table 2 Characteristics of Included Studies

\begin{tabular}{|c|c|c|c|c|c|}
\hline $\begin{array}{l}\text { Primary reference, Study, Country (secondary } \\
\text { references) }\end{array}$ & Objectives & Design & $\begin{array}{l}\text { Sample } \\
\text { size }\end{array}$ & $\begin{array}{l}\text { Patient } \\
\text { population }\end{array}$ & Follow-up \\
\hline \multicolumn{6}{|l|}{ Treatment-related observational studies } \\
\hline $\begin{array}{l}\text { Driessen } 2008 \text { [68], Radboud University Registry, The } \\
\text { Netherlands (Driessen } 2009 \text { [69]) }\end{array}$ & $\begin{array}{l}\text { Efficacy and tolerability of etenercept and } \\
\text { efalizumab }\end{array}$ & Registry & 118 & Psoriasis & 24 weeks \\
\hline Fortune 2003 [6], PUVA Study, UK and Ireland & $\begin{array}{l}\text { Role of psychological distress on PUVA } \\
\text { treatment outcomes }\end{array}$ & Cohort & 112 & $\begin{array}{l}\text { Plaque } \\
\text { psoriasis } \\
\text { (chronic) }\end{array}$ & 2 years \\
\hline Lecha 2005 [70], Spanish tacalcitol ointment study & Efficacy and tolerability of tacalcitol & Cohort & 556 & $\begin{array}{l}\text { Psoriasis } \\
\text { (moderate) }\end{array}$ & 2 months \\
\hline Naldi 2008 [71], Psocare, Italy & $\begin{array}{l}\text { Effect of BMl on clinical response to } \\
\text { systemic treatment }\end{array}$ & Cohort & 2368 & $\begin{array}{l}\text { Plaque } \\
\text { psoriasis }\end{array}$ & 3 years \\
\hline Paul 2003 [72] Cyclosporine study, Europe and Canada & $\begin{array}{l}\text { Incidence of malignancies in cyclosporine } \\
\text { treated patients }\end{array}$ & Cohort & 1252 & $\begin{array}{l}\text { psoriasis - } \\
\text { severe }\end{array}$ & 5 years \\
\hline Wahl 2005 [73], Climate therapy study, Norway & Effectiveness of climate therapy & Cohort & 286 & Psoriasis & 8 months \\
\hline $\begin{array}{l}\text { Heiberg } 2008 \text { [74], Norwegian register of disease } \\
\text { modifying anti-rheumatic drugs, (Heiberg } 2007 \text { [75]) }\end{array}$ & $\begin{array}{l}\text { Comparative effectiveness of TNF } \\
\text { inhibitors vs. methotrexate monotherapy }\end{array}$ & Registry & 526 & $\begin{array}{l}\text { Psoriatic } \\
\text { arthritis }\end{array}$ & 1 year \\
\hline $\begin{array}{l}\text { Kristensen } 2008 \text { [76], South Swedish Arthritis Treatment } \\
\text { Group register, (Gulfe } 2009 \text { [77], Geborek } 2002 \text { [78], } \\
\text { Kristensen } 2006 \text { [79]) }\end{array}$ & $\begin{array}{l}\text { Efficacy, utility and tolerability of TNF- } \\
\text { inhibitors (etanercept, infliximab, } \\
\text { adalimumab) }\end{array}$ & Registry & 261 & $\begin{array}{l}\text { Psoriatic } \\
\text { arthritis }\end{array}$ & 7 years \\
\hline Sparado 1997 [80], Cyclosporin Study, Italy & $\begin{array}{l}\text { Probability of continuing to take } \\
\text { cyclosporine vs. Other DMARDS }\end{array}$ & Cohort & 172 & $\begin{array}{l}\text { Psoriatic } \\
\text { arthritis }\end{array}$ & 10 years \\
\hline $\begin{array}{l}\text { Saad } 2009 \text { [81], British Society for Rheumatology } \\
\text { Biologics Register, (Harrison } 2009 \text { [82], Silman } 2003 \text { [83]) }\end{array}$ & $\begin{array}{l}\text { Effectiveness and tolerability of TNF- } \\
\text { inhibitors (etanercept, infliximab, } \\
\text { adalimumab) }\end{array}$ & Registry & 566 & $\begin{array}{l}\text { RA, psoriasis, } \\
\text { psoriatic } \\
\text { arthritis }\end{array}$ & 1 year \\
\hline \multicolumn{6}{|l|}{ Non-treatment related observational studies } \\
\hline Carrascosa 2006 [84], EPIDERMA cost of illness, Spain & $\begin{array}{l}\text { Direct and indirect cost; relationship } \\
\text { between cost and severity }\end{array}$ & Cohort & 797 & Psoriasis & 1 year \\
\hline Colombo 2008 [11], Cost of illness, Italy & $\begin{array}{l}\text { Direct and indirect cost; } \mathrm{HRQOL} \text {; } \\
\text { relationship between cost, HRQOL and } \\
\text { severity }\end{array}$ & Cohort & 150 & $\begin{array}{l}\text { Moderate to } \\
\text { severe } \\
\text { plaque } \\
\text { psoriasis }\end{array}$ & 3 months \\
\hline $\begin{array}{l}\text { Schmid-ott } 2005 \text { [85], Bad Bentheim Rehabilitation } \\
\text { Hospital, Germany }\end{array}$ & $\begin{array}{l}\text { Relationship between the degree of } \\
\text { stigmatisation and gender, skin symptoms, } \\
\text { PASI and SPASI }\end{array}$ & Cohort & 166 & Psoriasis & 1 year \\
\hline $\begin{array}{l}\text { Ali } 2007 \text { [86], Husted } 2007 \text { [2], Gladman } 2009 \text { [16], } \\
\text { Rohekar } 2008 \text { [87], Toronto PsA clinic, Canada, } \\
\text { (Chandran } 2007 \text { [88], Gladman } 1995 \text { [89], Gladman } 1998 \\
\text { [90], Gladman 1999 [91], Gladman 2001 [92], Husted } \\
\text { 2005 [93], Wong } 1997 \text { [94]) }\end{array}$ & $\begin{array}{l}\text { (1) Mortality associated with PsA; (2) } \\
\text { relationship between physical functioning, } \\
\text { disease activity and joint damage; ( } 3 \text { ) CVD } \\
\text { associated with PsA; (4) malignancies } \\
\text { associated with PSA }\end{array}$ & Cohort & $\begin{array}{l}382 \text { to } \\
680\end{array}$ & $\begin{array}{l}\text { Psoriatic } \\
\text { arthritis }\end{array}$ & 26 years \\
\hline $\begin{array}{l}\text { Kane } 2003 \text { [95], St. Vincent's University study, Ireland, } \\
\text { (Kane 2003a [96]) }\end{array}$ & $\begin{array}{l}\text { Clinical presentation, outcome and } \\
\text { prognosis of early PSA }\end{array}$ & Cohort & 129 & $\begin{array}{l}\text { Early psoriatic } \\
\text { arthritis }\end{array}$ & 2 years \\
\hline $\begin{array}{l}\text { Lindqvist } 2008 \text { [97], SwePsA registry, Sweden, (Svensson } \\
2002 \text { [98]) }\end{array}$ & $\begin{array}{l}\text { Factors associated with disease } \\
\text { progression; outcome of treated and non- } \\
\text { treated groups, comparison of outcomes } \\
\text { with RA patients }\end{array}$ & Registry & 135 & $\begin{array}{l}\text { Early psoriatic } \\
\text { arthritis }\end{array}$ & 2 years \\
\hline
\end{tabular}

PUVA, Psoralen Ultra-Violet A. TNF, Tumor Necrosis Factor. DMARD, disease-modifying anti-rheumatic drug. RA, rheumatoid arthritis. HRQOL, health-related quality of life.

are a number of situations where such studies may be unnecessary, inappropriate, impossible or inadequate [21]. The measurement of the effectiveness of a treatment, the longer-term outcomes of treatment (clinical and patient-reported), the true incidence of adverse events, and resource use associated with treatment and its side-effects are all situations where a RCT design is inadequate. RCT's often use patients, treatments and healthcare professionals that are all atypical and in addition are often short-term. Resource use and patient utilities observed in RCTs may not reflect that likely to be observed in regular clinical practice, not least because closer monitoring of patients in a trial may lead to events being detected and treated sooner than would otherwise be the case. This higher level of care may result in a small number of patients not experiencing 
Table 3 Clinical, patient-reported and cost measurements reported in included studies

\begin{tabular}{|c|c|c|c|}
\hline \multirow{2}{*}{$\begin{array}{l}\text { Study (first } \\
\text { author*) }\end{array}$} & \multicolumn{3}{|l|}{ Measurements } \\
\hline & Clinical & Patient-reported & Cost \\
\hline \multicolumn{4}{|c|}{ Treatment-related observational studies } \\
\hline $\begin{array}{l}\text { Driessen } 2008 \\
{[68]}\end{array}$ & PASI & - & - \\
\hline $\begin{array}{l}\text { Fortune } 2003 \\
{[6]}\end{array}$ & Time taken to achieve clearance of psoriasis & $\begin{array}{l}\text { Psychological distress, alcohol intake, } \\
\text { HADS }\end{array}$ & - \\
\hline $\begin{array}{l}\text { Lecha } 2005 \\
\quad[70]\end{array}$ & psoriasis severity and area, global efficacy and tolerability & $\begin{array}{l}\text { Patients' satisfaction [tools not } \\
\text { described]. }\end{array}$ & - \\
\hline $\begin{array}{l}\text { Naldi } 2008 \\
\quad[71]\end{array}$ & PASI, BMI & - & - \\
\hline $\begin{array}{l}\text { Paul 2003 } \\
\text { [72] }\end{array}$ & Malignancies & - & - \\
\hline $\begin{array}{l}\text { Wahl } 2005 \\
\quad[73]\end{array}$ & SPASI & $\begin{array}{l}\text { SF-36, one item on QOL and one } \\
\text { assessment of self-acceptance }\end{array}$ & - \\
\hline $\begin{array}{l}\text { Heiberg } 2008 \\
{[74]}\end{array}$ & DAS-28 & HAQ; SF-36; SF-6D (utility) & - \\
\hline $\begin{array}{l}\text { Kristensen } \\
2008[76]\end{array}$ & DAS-28, erythrocyte sedimentation rate and C-reactive protein & $\begin{array}{l}\text { EQ-5D (utility) HAQ, VAS-pain, VAS- } \\
\text { global, global evaluation }\end{array}$ & - \\
\hline $\begin{array}{l}\text { Sparado } 1997 \\
{[80]}\end{array}$ & $\begin{array}{l}\text { Type of therapy; drug continuation; Number of painful and swollen joints; } \\
\text { remission }\end{array}$ & - & - \\
\hline $\begin{array}{l}\text { Saad } 2009 \\
\quad[81]\end{array}$ & Drug persistence; DAS-28 & HAQ adapted for UK use and SF-36 & - \\
\hline \multicolumn{4}{|c|}{ Non-treatment related observational studies } \\
\hline $\begin{array}{l}\text { Carrascosa } \\
2006[84]\end{array}$ & PASI & & $\begin{array}{l}\text { Direct, } \\
\text { indirect }\end{array}$ \\
\hline $\begin{array}{l}\text { Colombo } \\
2008[11]\end{array}$ & PASI & SF-36, DLQI & $\begin{array}{l}\text { Direct, } \\
\text { indirect }\end{array}$ \\
\hline $\begin{array}{l}\text { Schmid-ott } \\
2005[85]\end{array}$ & PASI, SPASI & QES & - \\
\hline $\begin{array}{l}\text { Husted } 2007 \\
{[2]}\end{array}$ & $\begin{array}{l}\text { Mortality; PASI; Duration of morning stiffness, and total numbers of actively } \\
\text { inflamed joints; incidence of CVD; malignancies }\end{array}$ & $\mathrm{HAQ}$ & - \\
\hline $\begin{array}{c}\text { Kane } 2003 \\
{[95]}\end{array}$ & $\begin{array}{l}\text { PASI, Ritchie Articular Index, EULAR swollen joint count, joint stiffness on } \\
\text { waking. }\end{array}$ & $\mathrm{HAQ}$ & - \\
\hline $\begin{array}{l}\text { Lindqvist } \\
2008[97]\end{array}$ & $\begin{array}{l}66 / 68 \text { joint counts, PASI, physician's global assessment of joint disease activity, } \\
\text { and subclassification; remission }\end{array}$ & VAS, HAQ, SF-36 & - \\
\hline
\end{tabular}

*Primary paper for the study or the most recent analysis of the cohort.

high cost events that would be seen in everyday practice. In economic terms this is important since economic data is often highly skewed. The removal of a few observations with very high costs can have a large effect on overall health economic results. Also, RCTs are often conducted in specialist centres. The recorded resource consumption seen in the trial will therefore reflect the practice policies of this particular health care setting which may be very different to usual clinical practice. It is in such situations that observational cohort studies would provide more appropriate and informative health economic information if conducted and analysed rigorously.

Third, of those studies included in this review overall quality assessment was in general satisfactory, however the majority of studies failed to take into account and adjust for potential biases caused by lack of randomisation. Studies scored poorly on describing potential selection biases, identifying a comparison group, adjusting for confounders and losses to follow-up and providing adequate sample size calculations. The key question posed in cohort studies is the comparison of outcomes between two groups of patients (e.g. those responding to treatment vs. those not responding to treatment). Just over $60 \%$ of the studies in this review actually defined a comparison group, be it the general population or a more restricted internal or external population. For those studies not providing a comparison it is almost impossible to assess whether the results occurred by chance. Of those reporting a comparison group most 
Table 4 Quality assessment of included studies

\begin{tabular}{lllllllllllllllllllll}
\hline First author* & $\mathbf{1}$ & $\mathbf{2}$ & $\mathbf{3}$ & $\mathbf{4}$ & $\mathbf{5}$ & $\mathbf{6}$ & $\mathbf{7}$ & $\mathbf{8}$ & $\mathbf{9}$ & $\mathbf{1 0}$ & $\mathbf{1 1}$ & $\mathbf{1 2}$ & $\mathbf{1 3}$ & $\mathbf{1 4}$ & $\mathbf{1 5}$ & $\mathbf{1 6}$ & $\mathbf{1 7}$ & $\mathbf{1 8}$ & Sum \\
\hline Treatment-related observational studies & & & & & & & & & & & & \\
\hline Sriessen 2008 [66] & 1 & 1 & 1 & 0 & 1 & 1 & 0 & 1 & 1 & 1 & 1 & 1 & 1 & 1 & 1 & 0 & 0 & 0 & 13 \\
\hline Fortune 2003 [6] & 1 & 1 & 1 & 0 & 1 & 1 & 1 & 1 & 0 & 1 & 1 & 1 & 1 & 1 & 1 & 1 & 1 & 1 & 16 \\
\hline Lecha 2005 [68] & 1 & 1 & 1 & 0 & 1 & 0 & 1 & 1 & 1 & 1 & 1 & 1 & 0 & 0 & 0 & 0 & 0 & 0 & 10 \\
\hline Naldi 2008 [69] & 1 & 1 & 0 & 1 & 0 & 1 & 1 & 1 & na & 1 & 1 & 1 & 0 & 0 & 0 & 0 & 0 & 0 & 9 \\
\hline Paul 2003 [70] & 1 & 1 & 1 & 0 & 1 & 1 & 1 & 1 & 0 & 1 & 1 & 1 & 1 & 0 & 0 & 0 & 0 & 0 & 11 \\
\hline Wahl 2005 [71] & 1 & 1 & 1 & 0 & 0 & 0 & 1 & 1 & na & 1 & 1 & 0 & 0 & 0 & 0 & 0 & 0 & 0 & 7 \\
\hline Heiberg 2008 [72] & 1 & 1 & 1 & 1 & 1 & 1 & 1 & 1 & 1 & 1 & 1 & 1 & 1 & 1 & 1 & 0 & 0 & 0 & 15 \\
\hline Kristensen 2008 [74] & 1 & 1 & 1 & 1 & 1 & 1 & 1 & 1 & 1 & 1 & 1 & 1 & 1 & 0 & 1 & 0 & 0 & 0 & 14 \\
\hline Sparado 1997 [78] & 1 & 1 & 1 & 0 & 0 & 1 & 1 & 1 & 1 & 1 & 0 & 1 & 0 & 0 & 1 & 1 & 0 & 0 & 11 \\
\hline Saad 2009 [79] & 1 & 1 & 1 & 1 & 1 & 0 & 1 & 1 & 1 & 1 & 1 & 1 & 1 & 1 & 0 & 0 & 0 & 0 & 13 \\
\hline Non-treatment related observational studies & & & & & & & & & & & \\
\hline Carrascosa 2006 [82] & 1 & 1 & 1 & 1 & 1 & 0 & 1 & 1 & na & 1 & 0 & 1 & 0 & 0 & 1 & 1 & na & na & 11 \\
\hline Colombo 2008 [11] & 1 & 1 & 1 & 0 & 1 & 1 & 1 & 1 & na & 1 & 0 & 1 & 0 & 0 & 1 & 1 & na & na & 11 \\
\hline Schmid-ott 2005 [83] & 0 & 1 & 1 & 1 & 1 & 0 & 1 & 1 & na & 1 & 0 & 1 & 0 & 0 & 1 & 1 & na & na & 10 \\
\hline Husted 2007 [2] & 1 & 1 & 1 & 0 & 1 & 1 & 1 & 1 & na & 1 & 1 & 1 & 1 & 1 & 1 & 0 & na & na & 13 \\
\hline Kane 2003 [93] & 1 & 1 & 1 & 0 & 1 & 0 & 1 & 1 & na & 1 & 1 & 1 & 0 & 0 & 1 & 0 & na & na & 10 \\
\hline Lindqvist 2008 [95] & 1 & 1 & 1 & 0 & 1 & 1 & 1 & 1 & na & 1 & 1 & 1 & 1 & 1 & 0 & 0 & na & na & 12 \\
\hline
\end{tabular}

*Primary paper for the study or the most recent analysis of the cohort. NA, not applicable.

studies reported potential selection bias however only half accounted for confounders and only a third accounted for losses to follow-up. In those studies not addressing these issues of potential bias, results are likely to have very low internal validity. Adjusting for the potential bias caused by lack of randomisation is critical to the validity of cohort studies [59-61].

When interpreting the results of this systematic review it is important to note three issues. First, it is difficult to systematically search for observational studies as search

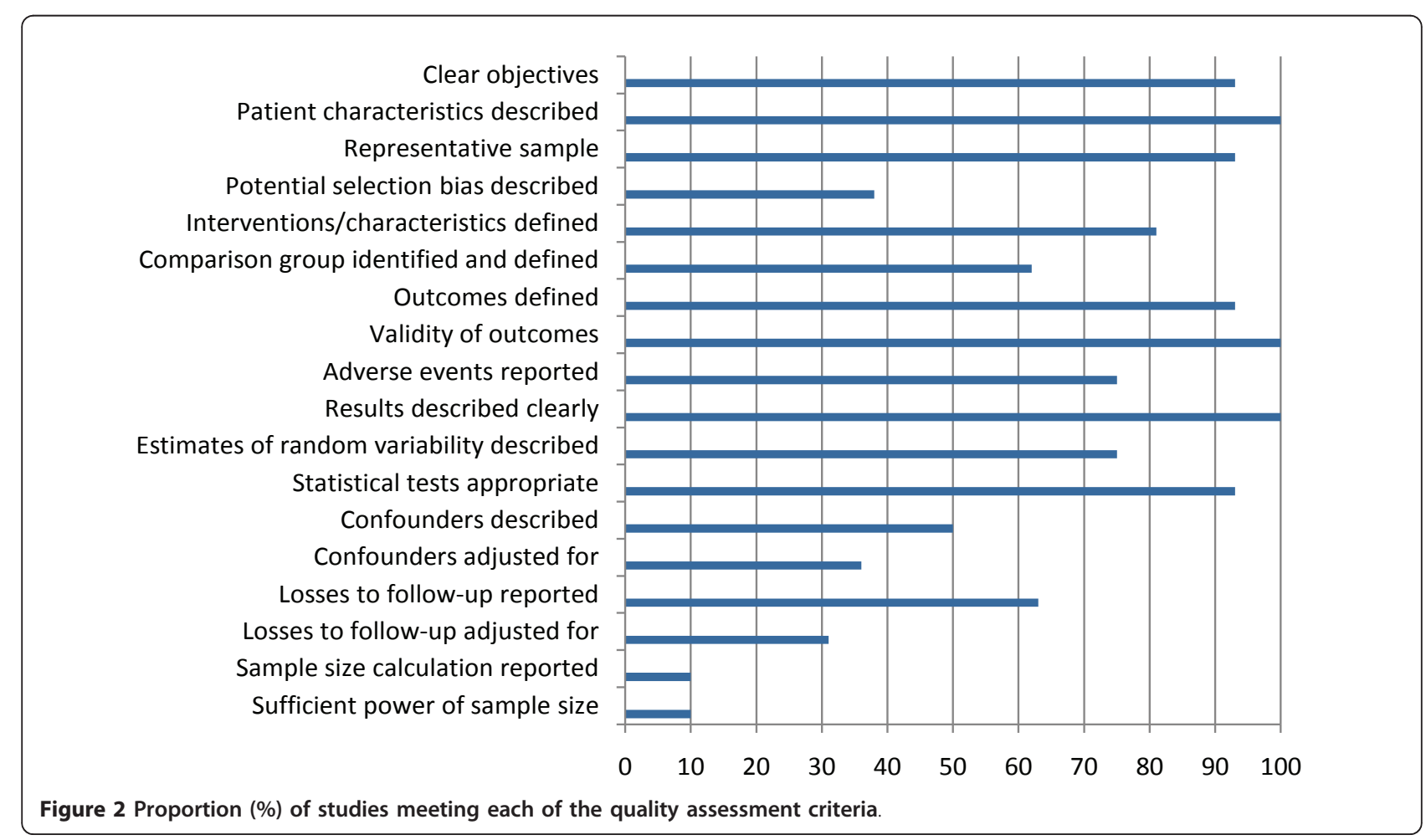


strategies that are both sensitive and specific do not exist for the major electronic databases. To overcome this problem we conducted a wide search and handsearched reference lists of key papers. Second, consensus guidelines on the reporting of observational studies (STROBE) have only recently been introduced [25], therefore for many studies published prior to these guidelines it is often difficult to identify if the paper is a true observational study or not. Many studies stated they were observational, but in actual fact incorporated an experimental or 'open-label' element to them. Third, the cut-off of 100 patients to define large scale may have meant other important observational studies were excluded. However, only one study was excluded on the basis of sample size [44].

Large scale, prospective cohort studies are not the only non-randomised method for capturing real world health economic data. They are however, if conducted rigorously one of the best approaches to use, especially for non-rare outcomes over a relatively short period. A number of cross-sectional and case-control studies assessing cost, effectiveness and HRQOL have been conducted in patients with psoriasis and psoriatic arthritis. Cross-sectional studies are useful for assessing prevalence and describing specific characteristics of the disease, for example clinical and demographic characteristics, patient and provider perceptions of effectiveness, tolerability and compliance. However, unless they incorporate a retrospective element into their design, they are unable to distinguish between cause and effect and therefore are inappropriate for the measurement of effectiveness and health economic outcomes associated with an intervention. Retrospective elements to observational studies, for example retrospectively identifying patients or retrospective data collection (as in case control studies) introduces an additional level of bias and are therefore often used for more descriptive studies or hypothesis generation that can then be studied in a prospective observational study.

Looking outside of true observational designs to studies which are non-randomised but incorporate an experimental element to them, we find a number of 'open-label' trials, some aiming to assess longer-term outcomes and others aiming to assess effectiveness in a more naturalistic setting. These studies are not observational, although many claim to be. They are experimental in that patients have been selected for inclusion into the trial and administered the trial treatment. Given that these studies are not governed by any consensus guidelines on reporting or quality control, the potential for risk of error or bias is high and the results should be interpreted with caution. Included in these designs are 'open-label' extension studies. Patients represent a highly select group that have not only been selected on the basis of the original RCT, but are also those who have completed the randomized element to the trial and agreed to participate in the extension study. Such selection processes not only introduces significant bias, but also lowers even further the generalisability of the results to a wider population. In such studies the use of inferential statistics to allow for the possibility of sampling or random error to be the reason for the observed difference is crucial. However, in most extension studies assessing effectiveness in psoriasis or psoriatic arthritis no such inferential statistics have been carried out [62-64]. Also included are 'open-label' studies which adopt a non-randomised approach from the start of the study. Again these studies should be interpreted with caution for two main reasons; first, treatment is experimental and has therefore been selected by an investigator not independent from the study and second, the patient will know which treatment they are being given. Both actions will introduce inadvertent bias into the outcome assessment. Furthermore it is essential that such studies conform to the same rigorous methods expected of true observational studies in that the bias created from non-randomisation should be defined, explored and adjusted for. Currently, apart from one 'open-label' phase IV study assessing health economic outcomes which does account for confounding [34], most of the others don't $[29,36,41]$.

\section{Conclusion}

There is a clear need for well designed, large-scale, prospective observational studies in the field of psoriasis and psoriatic arthritis particularly to assess the impact of traditional and biological agents on economic and patient-reported outcomes and the factors that influence them, such as resistance and adherence, in a real world environment. Several population-based registries are currently being set up for both psoriasis and psoriatic arthritis [58,65-67]. However, while such registries will no doubt provide invaluable evidence on the long-term risks and benefits of new and old treatments, they fall short of providing adequate information on health economic outcomes. The recommended core datasets for registries include effectiveness measures [58,67], HRQOL measures [67], but no patient utilities and insufficient information with which to measure health care resources or work productivity. Future observational studies measuring such outcomes would be a welcome addition to the scientific literature in this area and would provide invaluable information to patients, clinicians and policy makers.

\section{Author details}

${ }^{1}$ PHMR consulting, London, UK. '2Department of Public Health and Policy, Health Services Research Unit, London School of Hygiene and Tropical 
Medicine, London, UK. ${ }^{3}$ Novartis Pharma AG, Health Economics \& Outcomes Research, Basel, Switzerland.

\section{Authors' contributions}

HPG and MR were responsible for the conception and design of the study. $S L$ and $J L$ conducted the data analysis. SL, JL, HPG and MR interpreted the results. SL led drafting and revision of the manuscript. JL, HPG and MR contributed to revising the manuscript critically for important intellectual content. All authors approved the final version of the manuscript.

\section{Competing interests}

This project was funded by Novartis Pharma AG. Dr. Langham and Dr. Ratcliffe are affiliated at PHMR Consulting. Mr. Goertz is affiliated at Novartis Pharma AG.

Received: 30 April 2010 Accepted: 31 March 2011 Published: 31 March 2011

\section{References}

1. Augustin M, Kruger K, Radtke MA, Schwippl I, Reich K: Disease Severity, Quality of Life and Health Care in Plaque-Type Psoriasis: a Multicenter Cross-Sectional Study in Germany. Dermatology 2008, 216(4):366-72.

2. Husted JA, Tom BD, Farewell VT, Schentag CT, Gladman DD: A Longitudinal Study of the Effect of Disease Activity and Clinical Damage on Physical Function Over the Course of Psoriatic Arthritis: Does the Effect Change Over Time? Arthritis Rheum 2007, 56(3):840-9.

3. Unaeze J, Nijsten T, Murphy A, Ravichandran C, Stern RS: Impact of Psoriasis on Health-Related Quality of Life Decreases Over Time: an 11Year Prospective Study. J Invest Dermatol 2006, 126(7):1480-9.

4. Stern RS, Nijsten T, Feldman SR, Margolis DJ, Rolstad T: Psoriasis Is Common, Carries a Substantial Burden Even When Not Extensive, and Is Associated With Widespread Treatment Dissatisfaction. J Investig Dermatol Symp Proc 2004, 9(2):136-9.

5. Gelfand JM, Feldman SR, Stern RS, Thomas J, Rolstad T, Margolis DJ: Determinants of Quality of Life in Patients With Psoriasis: a Study From the US Population. J Am Acad Dermatol 2004, 51(5):704-8.

6. Fortune DG, Richards HL, Kirby B, McElhone K, Markham T, Rogers S, Main CJ, Griffiths CE: Psychological Distress Impairs Clearance of Psoriasis in Patients Treated With Photochemotherapy. Arch Dermatol 2003, 139(6):752-6.

7. Esposito M, Saraceno R, Giunta A, Maccarone M, Chimenti S: An Italian Study on Psoriasis and Depression. Dermatology 2006, 212(2):123-7.

8. Schmitt JM, Ford DE: Role of Depression in Quality of Life for Patients With Psoriasis. Dermatology 2007, 215(1):17-27.

9. Rapp SR, Feldman SR, Exum ML, Fleischer AB Jr, Reboussin DM: Psoriasis Causes As Much Disability As Other Major Medical Diseases. J Am Acad Dermatol 1999, 41(3 Pt 1):401-7.

10. Schmitt JM, Ford DE: Work Limitations and Productivity Loss Are Associated With Health-Related Quality of Life but Not With Clinical Severity in Patients With Psoriasis. Dermatology 2006, 213(2):102-10.

11. Colombo G, Altomare G, Peris K, Martini P, Quarta G, Congedo M, Costanzo A, Di Cesare A, Lapucci E, Chimenti S: Moderate and Severe Plaque Psoriasis: Cost-of-IIIness Study in Italy. Ther Clin Risk Manag 2008, 4(2):559-68.

12. Javitz HS, Ward MM, Farber E, Nail L, Vallow SG: The Direct Cost of Care for Psoriasis and Psoriatic Arthritis in the United States. J Am Acad Dermatol 2002, 46(6):850-60.

13. Berger K, Ehlken B, Kugland B, Augustin M: Cost-of-Illness in Patients With Moderate and Severe Chronic Psoriasis Vulgaris in Germany. J Dtsch Dermatol Ges 2005, 3(7):511-8.

14. Poikolainen K, Karvonen J, Pukkala E: Excess Mortality Related to Alcohol and Smoking Among Hospital-Treated Patients With Psoriasis. Arch Dermatol 1999, 135(12):1490-3.

15. Frentz G, Olsen JH: Malignant Tumours and Psoriasis: a Follow-Up Study. Br J Dermatol 1999, 140(2):237-42

16. Gladman DD, Ang M, Su L, Tom BD, Schentag CT, Farewell VT: Cardiovascular Morbidity in Psoriatic Arthritis. Ann Rheum Dis 2009, 68(7):1131-5.

17. Gelfand JM, Troxel AB, Lewis JD, Kurd SK, Shin DB, Wang X, Margolis DJ, Strom BL: The Risk of Mortality in Patients With Psoriasis: Results From a Population-Based Study. Arch Dermatol 2007, 143(12):1493-9.
18. Bansback N, Sizto S, Sun H, Feldman S, Willian MK, Anis A: Efficacy of Systemic Treatments for Moderate to Severe Plaque Psoriasis: Systematic Review and Meta-Analysis. Dermatology 2009, 219(3):209-18.

19. Schmitt J, Zhang Z, Wozel G, Meurer M, Kirch W: Efficacy and Tolerability of Biologic and Nonbiologic Systemic Treatments for Moderate-toSevere Psoriasis: Meta-Analysis of Randomized Controlled Trials. $\mathrm{Br} J$ Dermatol 2008, 159(3):513-26.

20. Bombardier C, Maetzel A: Pharmacoeconomic Evaluation of New Treatments: Efficacy Versus Effectiveness Studies? Ann Rheum Dis 1999, 58(Suppl 1):182-185.

21. Black N: Why We Need Observational Studies to Evaluate the Effectiveness of Health Care. BMJ 1996, 312(7040):1215-8.

22. Rawlins M: De Testimonio: on the Evidence for Decisions About the Use of Therapeutic Interventions. Lancet 2008, 20(9656):2152-61, 372.

23. Woolacott N, Bravo W, Hawkins N, Kainth A, Khadjesari Z, Misso K, et al: Etanercept and infliximab for the treatment of psoriatic arthritis: a systematic review and economic evaluation. Health Technol Assess 2006, 10:iii-xvi, 1.

24. Linde K, Knuppel L: Large-scale observational studies of hypericum extracts in patients with depressive disorders-a systematic review. Phytomedicine 2005, 12:148-157

25. von Elm E, Altman DG, Egger M, Pocock SJ, Gotzsche PC, Vandenbroucke JP: The Strengthening the Reporting of Observational Studies in Epidemiology (STROBE) Statement: Guidelines for Reporting Observational Studies. Ann Intern Med 2007, 147(8):573-7.

26. Sanderson S, Tatt ID, Higgins JP: Tools for Assessing Quality and Susceptibility to Bias in Observational Studies in Epidemiology: a Systematic Review and Annotated Bibliography. Int J Epidemiol 2007, 36(3):666-76.

27. Downs SH, Black N: The Feasibility of Creating a Checklist for the Assessment of the Methodological Quality Both of Randomised and Non-Randomised Studies of Health Care Interventions. J. Epidemiol Community Health 1998, 52(6):377-84.

28. Tabolli S, Calza A, Di Pietro C, Sampogna F, Abeni D: Quality of Life of Psoriasis Patients Before and After Balneo - or Balneophototherapy. Yonsei Med J 2009, 50(2):215-21.

29. Feldman SR: Effectiveness of Clobetasol Propionate Spray $0.05 \%$ Added to Other Stable Treatments: Add-on Therapy in the COBRA Trial. Cutis 2007, 80(5 Suppl):20-8.

30. Koo JY: Relevance of the COBRA Trial in Current Psoriasis Practice. Cutis 2007, 80(5 Suppl):4-11.

31. Lebwohl M, Colon LE: The Evolving Role of Topical Treatments in Adjunctive Therapy for Moderate to Severe Plaque Psoriasis. Cutis 2007 80(5 Suppl):29-40.

32. Menter A: Topical Monotherapy With Clobetasol Propionate Spray $0.05 \%$ in the COBRA Trial. Cutis 2007, 80(5 Suppl):12-9.

33. Frankel EH, Strober BE, Crowley JJ, Fivenson DP, Woolley JM, Yu EB, Xia HA, Chiou CF, Stevens SR: Etanercept Improves Psoriatic Arthritis PatientReported Outcomes: Results From EDUCATE. Cutis 2007, 79(4):322-6.

34. Gottlieb AB, Kircik L, Eisen D, Jackson JM, Boh EE, Strober BE, Frankel E, Xia HA, Stevens SR: Use of Etanercept for Psoriatic Arthritis in the Dermatology Clinic: the Experience Diagnosing, Understanding Care, and Treatment With Etanercept (EDUCATE) Study. J Dermatolog Treat 2006, 17(6):343-52

35. Gottlieb AB, Mease PJ, Mark, Jackson J, Eisen D, Amy, Xia H, Asare C, Stevens SR: Clinical Characteristics of Psoriatic Arthritis and Psoriasis in Dermatologists' Offices. J Dermatolog Treat 2006, 17(5):279-87.

36. Kimball AB, Jackson JM, Sobell JM, Boh EE, Grekin S, Pharmd EB, Woolley JM, Xia HA, Chiou CF, Stevens SR: Reductions in Healthcare Resource Utilization in Psoriatic Arthritis Patients Receiving Etanercept Therapy: Results From the Educate Trial. J Drugs Dermatol 2007, 6(3):299-306

37. Lambert J, Trompke C: Tacalcitol Ointment for Long-Term Control of Chronic Plaque Psoriasis in Dermatological Practice. Dermatology 2002, 204(4):321-4.

38. Mazzotta A, Esposito M, Costanzo A, Chimenti S: Efficacy and Safety of Etanercept in Psoriasis After Switching From Other Treatments: an Observational Study. Am J Clin Dermatol 2009, 10(5):319-24.

39. Schiffner R, Schiffner-Rohe J, Gerstenhauer M, Hofstadter F, Landthaler M, Stolz W: Willingness to Pay and Time Trade-Off: Sensitive to Changes of Quality of Life in Psoriasis Patients? Br J Dermatol 2003, 148(6):1153-60. 
40. Schiffner R, Schiffner-Rohe J, Gerstenhauer M, Hofstadter F, Landthaler M, Stolz W: Differences in Efficacy Between Intention-to-Treat and PerProtocol Analyses for Patients With Psoriasis Vulgaris and Atopic Dermatitis: Clinical and Pharmacoeconomic Implications. Br J Dermatol 2001, 144(6):1154-60.

41. Tanghetti EA: An Observation Study Evaluating the Efficacy of Tazarotene Plus Corticosteroid in Treating Plaque Psoriasis in Patients Switched From Treatment With Calcipotriene +/- Corticosteroid. Cutis 2000, 66(6 Suppl):12-8.

42. Tanghetti EA: An Observation Study Evaluating the Treatment of Plaque Psoriasis With Tazarotene Gels, Alone and With an Emollient and/or Corticosteroid. Cutis 2000, 66(6 Suppl):4-11.

43. Thaci D, Daiber W, Boehncke WH, Kaufmann R: Calcipotriol Solution for the Treatment of Scalp Psoriasis: Evaluation of Efficacy, Safety and Acceptance in 3,396 Patients. Dermatology 2001, 203(2):153-6.

44. Lim C, Brown P: Quality of Life in Psoriasis Improves After Standardized Administration of Narrowband UVB Phototherapy. Australas J Dermatol 2006, 47(1):37-40.

45. Nijsten T, Looman CW, Stern RS: Clinical Severity of Psoriasis in Last 20 Years of PUVA Study. Arch Dermatol 2007, 143(9):1113-21.

46. Stern RS, Lange R: Cardiovascular Disease, Cancer, and Cause of Death in Patients With Psoriasis: 10 Years Prospective Experience in a Cohort of 1,380 Patients. J Invest Dermatol 1988, 91(3):197-201.

47. Stern RS: Long-Term Use of Psoralens and Ultraviolet A for Psoriasis: Evidence for Efficacy and Cost Savings. J Am Acad Dermatol 1986, 14(3):520-6.

48. Forman AB, Roenigk HH Jr, Caro WA, Magid ML: Long-Term Follow-Up of Skin Cancer in the PUVA-48 Cooperative Study. Arch Dermatol 1989, 125(4):515-9.

49. Henseler T, Christophers E, Honigsmann H, Wolff K: Skin Tumors in the European PUVA Study. Eight-Year Follow-Up of 1,643 Patients Treated With PUVA for Psoriasis. J Am Acad Dermatol 1987, $16(1$ Pt 1):108-16.

50. Stern RS: The Risk of Melanoma in Association With Long-Term Exposure to PUVA. J Am Acad Dermatol 2001, 44(5):755-61.

51. Lindelof $B$, Sigurgeirsson B, Tegner $E$, Larko $O$, Johannesson A, Berne B, Ljunggren B, Andersson T, Molin L, Nylander-Lundqvist E, Emtestam L: PUVA and Cancer Risk: the Swedish Follow-Up Study. Br J Dermatol 1999, 141(1):108-12.

52. Hannuksela A, Pukkala E, Hannuksela M, Karvonen J: Cancer Incidence Among Finnish Patients With Psoriasis Treated With Trioxsalen Bath PUVA. J Am Acad Dermatol 1996, 35(5 Pt 1):685-9.

53. Bhosle MJ, Feldman SR, Camacho FT, Timothy, Whitmire J, Nahata MC, Balkrishnan R: Medication Adherence and Health Care Costs Associated With Biologics in Medicaid-Enrolled Patients With Psoriasis. J Dermatolog Treat 2006, 17(5):294-301.

54. Wu EQ, Feldman SR, Chen L, Kaltenboeck A, Yu AP, Gupta SR, Laitinen D, Willian MK: Utilization Pattern of Etanercept and Its Cost Implications in Moderate to Severe Psoriasis in a Managed Care Population. Curr Med Res Opin 2008, 24(12):3493-501.

55. Nast A, Reytan N, Rosumeck S, Erdmann R, Rzany B: Low Prescription Rate for Systemic Treatments in the Management of Severe Psoriasis Vulgaris and Psoriatic Arthritis in Dermatological Practices in Berlin and Brandenburg, Germany: Results From a Patient Registry. J Eur Acad Dermatol Venereol 2008, 22(11):1337-42.

56. O'Neill T, Silman AJ: Psoriatic Arthritis. Historical Background and Epidemiology. Baillieres Clin Rheumatol 1994, 8(2):245-61.

57. Fowler JF, Duh MS, Rovba L, Buteau S, Pinheiro L, Lobo F, Sung J, Doyle JJ, Swensen A, Mallett DA, Kosicki G: The Impact of Psoriasis on Health Care Costs and Patient Work Loss. J Am Acad Dermatol 2008, 59(5):772-80.

58. Lecluse LL, Naldi L, Stern RS, Spuls PI: National Registries of Systemic Treatment for Psoriasis and the European 'Psonet' Initiative. Dermatology 2009, 218(4):347-56.

59. Rochon PA, Gurwitz JH, Sykora K, Mamdani M, Streiner DL, Garfinkel S, Normand SL, Anderson GM: Reader's Guide to Critical Appraisal of Cohort Studies: 1. Role and Design. BMJ 2005, 330(7496):895-7.

60. Mamdani M, Sykora K, Li P, Normand SL, Streiner DL, Austin PC, Rochon PA, Anderson GM: Reader's Guide to Critical Appraisal of Cohort Studies: 2. Assessing Potential for Confounding. BMJ 2005, 330(7497):960-2.

61. Normand SL, Sykora K, Li P, Mamdani M, Rochon PA, Anderson GM: Readers Guide to Critical Appraisal of Cohort Studies: 3. Analytical Strategies to Reduce Confounding. BMJ 2005, 330(7498):1021-3.
62. Mease PJ, Reich K: Alefacept With Methotrexate for Treatment of Psoriatic Arthritis: Open-Label Extension of a Randomized, Double-Blind, Placebo-Controlled Study. J Am Acad Dermatol 2009, 60(3):402-11.

63. Mease PJ, Kivitz AJ, Burch FX, Siegel EL, Cohen SB, Ory P, Salonen D, Rubenstein J, Sharp JT, Tsuji W: Etanercept Treatment of Psoriatic Arthritis: Safety, Efficacy, and Effect on Disease Progression. Arthritis Rheum 2004, 50(7):2264-72

64. Sterry W, Stingl G, Langley RG, Zacharie H, Lahfa M, Giannetti A, Ferrandiz C, Sinclair R, Saurat JH: Clinical Experience Acquired With Raptiva (CLEAR) Trial in Patients With Moderate-to-Severe Plaque Psoriasis: Results From Extended Treatment in an International, Phase III, Placebo-Controlled Trial. J Dtsch Dermatol Ges 2006, 4(11):947-56.

65. Hetland ML: DANBIO: a Nationwide Registry of Biological Therapies in Denmark. Clin Exp Rheumatol 2005, 23(5 Suppl 39):S205-S207.

66. Schmitt-Egenolf M: PsoReg-the Swedish Registry for Systemic Psoriasis Treatment. The Registry's Design and Objectives. Dermatology 2007, 214(2):112-7

67. Gladman DD, Rahman P, Krueger GG, Mease PJ, Qureshi AA, Dutz JP, Lindqvist U, Carneiro S, Helliwell PS, Ujfalussy I, Gottlieb AB, Behrens F, Stahle M: Clinical and Genetic Registries in Psoriatic Disease. J Rheumatol 2008, 35(7):1458-63.

68. Driessen RJ, Berends MA, Boezeman JB, Van De Kerkhof PC, De Jong EM: Psoriasis Treatment With Etanercept and Efalizumab: Clinical Strategies Influencing Treatment Outcome. Br J Dermatol 2008, 158(5):1098-106.

69. Driessen RJ, Boezeman JB, Van De Kerkhof PC, De Jong EM: Three-Year Registry Data on Biological Treatment for Psoriasis: the Influence of Patient Characteristics on Treatment Outcome. Br J Dermatol 2009, 160(3):670-5.

70. Lecha M, Mirada A, Lopez S, Artes M: Tacalcitol in the Treatment of Psoriasis Vulgaris: the Spanish Experience. J Eur Acad Dermatol Venereol 2005, 19(4):414-7.

71. Naldi L, Addis A, Chimenti S, Giannetti A, Picardo M, Tomino C, Maccarone M, Chatenoud L, Bertuccio P, Caggese E, Cuscito R: Impact of Body Mass Index and Obesity on Clinical Response to Systemic Treatment for Psoriasis. Evidence From the Psocare Project. Dermatology 2008, 217(4):365-73.

72. Paul CF, Ho VC, McGeown C, Christophers E, Schmidtmann B, Guillaume JC, Lamarque $V$, Dubertret L: Risk of Malignancies in Psoriasis Patients Treated With Cyclosporine: a 5 y Cohort Study. J Invest Dermatol 2003, 120(2):211-6.

73. Wahl AK, Mork C, Cooper BA, Padilla G: No Long-Term Changes in Psoriasis Severity and Quality of Life Following Climate Therapy. J Am Acad Dermatol 2005, 52(4):699-701.

74. Heiberg MS, Koldingsnes W, Mikkelsen K, Rodevand E, Kaufmann C, Mowinckel P, Kvien TK: The Comparative One-Year Performance of AntiTumor Necrosis Factor Alpha Drugs in Patients With Rheumatoid Arthritis, Psoriatic Arthritis, and Ankylosing Spondylitis: Results From a Longitudinal, Observational, Multicenter Study. Arthritis Rheum 2008, 59(2):234-40.

75. Heiberg MS, Kaufmann C, Rodevand E, Mikkelsen K, Koldingsnes W, Mowinckel P, Kvien TK: The Comparative Effectiveness of Anti-TNF Therapy and Methotrexate in Patients With Psoriatic Arthritis: 6 Month Results From a Longitudinal, Observational, Multicentre Study. Ann Rheum Dis 2007, 66(8):1038-42.

76. Kristensen LE, Gulfe A, Saxne T, Geborek P: Efficacy and Tolerability of Anti-Tumour Necrosis Factor Therapy in Psoriatic Arthritis Patients: Results From the South Swedish Arthritis Treatment Group Register. Ann Rheum Dis 2008, 67(3):364-9.

77. Gulfe A, Kristensen LE, Saxne T, Jacobsson LT, Petersson IF, Geborek P: Rapid and Sustained Health Utility Gain in Anti-TNF Treated Inflammatory Arthritis. Observational Data During Seven Years in Southern Sweden. Ann Rheum Dis 2009, p-ÿÿÿ.

78. Geborek P, Crnkic M, Petersson IF, Saxne T: Etanercept, Infliximab, and Leflunomide in Established Rheumatoid Arthritis: Clinical Experience Using a Structured Follow Up Programme in Southern Sweden. Ann Rheum Dis 2002, 61(9):793-8.

79. Kristensen LE, Saxne T, Nilsson JA, Geborek P: Impact of Concomitant DMARD Therapy on Adherence to Treatment With Etanercept and Infliximab in Rheumatoid Arthritis. Results From a Six-Year Observational Study in Southern Sweden. Arthritis Res Ther 2006, 8(6):R174. 
80. Spadaro A, Taccari E, Mohtadi B, Riccieri V, Sensi F, Zoppini : A. Life-Table Analysis of Cyclosporin A Treatment in Psoriatic Arthritis: Comparison With Other Disease-Modifying Antirheumatic Drugs. Clin Exp Rheumatol 1997, 15(6):609-14.

81. Saad AA, Ashcroft DM, Watson KD, Hyrich KL, Noyce PR, Symmons DP: Persistence With Anti-Tumour Necrosis Factor Therapies in Patients With Psoriatic Arthritis: Observational Study From the British Society of Rheumatology Biologics Register. Arthritis Res Ther 2009, 11(2):R52.

82. Harrison MJ, Dixon WG, Watson KD, King Y, Groves R, Hyrich KL, Symmons DP: Rates of New-Onset Psoriasis in Patients With Rheumatoid Arthritis Receiving Anti-Tumour Necrosis Factor Alpha Therapy: Results From the British Society for Rheumatology Biologics Register. Ann Rheum Dis 2009, 68(2):209-15.

83. Silman A, Symmons D, Scott DG, Griffiths I: British Society for Rheumatology Biologics Register. Ann Rheum Dis 2003, 62(Suppl 2):ii28-9, ii28-ii29.

84. Carrascosa JM, Pujol R, Dauden E, Hernanz-Hermosa JM, Bordas X, Smandia JA, Ferrandiz C: A Prospective Evaluation of the Cost of Psoriasis in Spain (EPIDERMA Project: Phase II). J Eur Acad Dermatol Venereol 2006, 20(7):840-5.

85. Schmid-Ott G, Kunsebeck HW, Jager B, Sittig U, Hofste N, Ott R, Malewski P, Lamprecht F: Significance of the Stigmatization Experience of Psoriasis Patients: a 1-Year Follow-Up of the Illness and Its Psychosocial Consequences in Men and Women. Acta Derm Venereol 2005, 85(1):27-32.

86. Ali Y, Tom BD, Schentag CT, Farewell VT, Gladman DD: Improved Survival in Psoriatic Arthritis With Calendar Time. Arthritis Rheum 2007, 56(8):2708-14.

87. Rohekar S, Tom BD, Hassa A, Schentag CT, Farewell VT, Gladman DD: Prevalence of Malignancy in Psoriatic Arthritis. Arthritis Rheum 2008, 58(1):82-7.

88. Chandran V, Bhella S, Schentag C, Gladman DD: Functional Assessment of Chronic Illness Therapy-Fatigue Scale Is Valid in Patients With Psoriatic Arthritis. Ann Rheum Dis 2007, 66(7):936-9.

89. Gladman DD, Farewell VT, Nadeau C: Clinical Indicators of Progression in Psoriatic Arthritis: Multivariate Relative Risk Model. J Rheumatol 1995, 22(4):675-9.

90. Gladman DD, Farewell VT, Wong K, Husted J: Mortality Studies in Psoriatic Arthritis: Results From a Single Outpatient Center. II. Prognostic Indicators for Death. Arthritis Rheum 1998, 41(6):1103-10.

91. Gladman DD, Farewell VT: Progression in Psoriatic Arthritis: Role of Time Varying Clinical Indicators. J Rheumatol 1999, 26(11):2409-13.

92. Gladman DD, Hing EN, Schentag CT, Cook RJ: Remission in Psoriatic Arthritis. J Rheumatol 2001, 28(5):1045-8.

93. Husted JA, Tom BD, Farewell VT, Schentag CT, Gladman DD: Description and Prediction of Physical Functional Disability in Psoriatic Arthritis: a Longitudinal Analysis Using a Markov Model Approach. Arthritis Rheum 2005, 53(3):404-9.

94. Wong K, Gladman DD, Husted J, Long JA, Farewell VT: Mortality Studies in Psoriatic Arthritis: Results From a Single Outpatient Clinic. I. Causes and Risk of Death. Arthritis Rheum 1997, 40(10):1868-72.

95. Kane D, Stafford L, Bresnihan B, FitzGerald O: A Prospective, Clinical and Radiological Study of Early Psoriatic Arthritis: an Early Synovitis Clinic Experience. Rheumatology (Oxford) 2003, 42(12):1460-8.

96. Kane D, Stafford L, Bresnihan B, FitzGerald O: A Classification Study of Clinical Subsets in an Inception Cohort of Early Psoriatic Peripheral Arthritis-'DIP or Not DIP Revisited'. Rheumatology (Oxford) 2003, 42(12):1469-76.

97. Lindqvist UR, Alenius GM, Husmark T, Theander E, Holmstrom G, Larsson PT: The Swedish Early Psoriatic Arthritis Register- 2-Year Followup: a Comparison With Early Rheumatoid Arthritis. J Rheumatol 2008, 35(4):668-73.

98. Svensson B, Holmstrom G, Lindqvist U: Development and Early Experiences of a Swedish Psoriatic Arthritis Register. Scand J Rheumatol 2002, 31(4):221-5.

\section{Pre-publication history}

The pre-publication history for this paper can be accessed here:

http://www.biomedcentral.com/1471-2288/11/32/prepub

\section{doi:10.1186/1471-2288-11-32}

Cite this article as: Langham et al:: Large-scale, prospective, observational studies in patients with psoriasis and psoriatic arthritis: A systematic and critical review. BMC Medical Research Methodology 2011 11:32.

\section{Submit your next manuscript to BioMed Central and take full advantage of:}

- Convenient online submission

- Thorough peer review

- No space constraints or color figure charges

- Immediate publication on acceptance

- Inclusion in PubMed, CAS, Scopus and Google Scholar

- Research which is freely available for redistribution

Submit your manuscript at www.biomedcentral.com/submit
Biomed Central 